\title{
A comparative study of some commercially available tests for rheumatoid factor
}

\author{
R. N. M. MacSWEEN, HAZEL HUGHES, CATRIONA BREEN, P. KITCHEN, \\ BRENDA CATHCART, AND W. W. BUCHANAN
}

From the University of Glasgow, Department of Pathology, Western Infirmary, Glasgow, and the Regional Immunopathology Laboratory, Centre for Rheumatic Diseases, Baird Street, Glasgow

SYNOPSIS Seven commercially available screening tests for rheumatoid factor and two quantitative tests have been compared with the standard Rose-Waaler test in a series of 477 sera from patients with various joint diseases. Markedly different results were obtained, and on the basis of our findings suggestions are made as to what we consider to be the most satisfactory currently available tests.

An increasing number of rapid screening tests for rheumatoid factor (RF) have recently become available, and as yet no satisfactory study of their relative sensitivities as screening procedures has been reported. In this context screening is defined as a preliminary testing for rheumatoid factor, a positive test indicating the need for a further quantitative estimation. In a routine immunopathology laboratory such as ours, handling over 6000 serum specimens per annum, it is considered essential that the screening procedures used provide the most accurate

Received for publication 4 March 1974. results. In agreement with the companies concerned it was decided to undertake a comparative serological examination for RF in a large number of serum specimens, using the standard Rose-Waaler test as the comparative reference. This communication presents the results obtained.

\section{Materials and Methods}

The test reagents used, the coding reference for each, the basis of each, and the manufacturers and distributors of each reagent are listed alphabetically in table I. All the reagents used were kindly donated

\begin{tabular}{|c|c|c|c|}
\hline Test Reagent & Coding & $\begin{array}{l}\text { Cost per } 1000 \\
\text { Tests unless } \\
\text { Otherwise Stated }\end{array}$ & Suppliers in United Kingdom \\
\hline $\begin{array}{l}\text { Bacto RA latex test }{ }^{1} \\
\text { Bacto rheumatoid slide test }{ }^{3} \\
\quad(\text { eosin latex test) } \\
\text { Bacto rheumatoid titration }{ }^{1} \text { test }\end{array}$ & $\begin{array}{l}\text { Di L } \\
\text { Di S } \\
\text { Di Tit }\end{array}$ & $\begin{array}{l}£ 60 \\
£ 47 \cdot 50 \\
£ 7 \cdot 12 \text { for } 50 / 65\end{array}$ & $\left\{\begin{array}{l}\text { Difco Laboratories, } \\
\text { PO Box 14B, East Molesey, } \\
\text { Surrey, KT8 0SE, England }\end{array}\right.$ \\
\hline Behringwerke-Latex $\operatorname{RF}^{1}$ reagent & $\operatorname{Be~L~}$ & $£ 38$ & $\left\{\begin{array}{l}\text { Hoechst Pharmaceuticals, } \\
\text { Hoechst House, Salisbury Road } \\
\text { Hounslow, Middlesex, England }\end{array}\right.$ \\
\hline Hyland RA test ${ }^{2}$ & Hy L & $£ 38$ & $\left\{\begin{array}{l}\text { Travenol Laboratories Ltd, } \\
\text { Caxton Way, Thetford, } \\
\text { Norfolk, England }\end{array}\right.$ \\
\hline $\begin{array}{l}\mathbf{R}_{8} \text { screen test }{ }^{2} \\
\mathbf{R}_{3} \text { titration test } \\
\text { Rheumaton reagent }\end{array}$ & $\begin{array}{l}\mathbf{R}_{3} \mathbf{L} \\
\mathbf{R}_{3} \text { Tit } \\
\text { Rheum. }\end{array}$ & $\begin{array}{l}£ 45 \\
£ 3 \cdot 25 \text { for } 25 / 50 \\
£ 150\end{array}$ & $\left\{\begin{array}{l}\text { Wm R. Warner \& Co Ltd, } \\
\text { Chestnut Avenue, Eastleigh, } \\
\text { Hampshire, SO5 3SQ, England }\end{array}\right.$ \\
\hline Rheum-Wellcotest ${ }^{1}$ & We L & $£ 40$ & $\left\{\begin{array}{l}\text { Wellcome Reagents, } \\
\text { Wellcome Research Laboratories, Beckenham, } \\
\text { Kent, BR3 3BS, England }\end{array}\right.$ \\
\hline
\end{tabular}

Table I Test reagents used, basis of test, coding reference in test, cost, and suppliers

$\int^{1}$ Latex particle sensitized with human $\gamma$-globulin Basis of test $\left\{\begin{array}{l}\text { 'Latex particle sensitized with bovine } \gamma \text {-globulin } \\ \text { 'Latex particle not sensitized }\end{array}\right.$

(Sheep erythrocytes sensitized with rabbit $\gamma$-globulin 
by the companies concerned, and in addition Wellcome Reagents supplied the materials for the RoseWaaler testing. The same batch of each reagent was used throughout the studies.

\section{SERA TESTED}

The details of the sera screened are summarized in table II. The initial selection of the sera to be screened was made on the basis of the clinical diagnosis, except of course for group IV. Allocation to sero-positive or sero-negative rheumatoid arthritis was made on the basis of the Rose-Waaler test. The 100 sera comprising group IV were sent to the laboratory for various antibody tests over a 10-day period during the survey; they were included irrespective of the provisional clinical diagnosis on the request form.

\begin{tabular}{llll}
\hline Group & Clinical Diagnosis & No. Screened \\
\hline I & Rheumatoid arthritis: sero-positive & 189 \\
II & Rheumatoid arthritis: sero-negative 51 & \\
& Gout & 12 & 88 \\
& Reiter's syndrome & 12 & 88 \\
& Ankylosing spondylitis & 13 & \\
III & Osteoarthritis & 100 \\
IV & 'Unselected' sera referred to laboratory & 100 \\
& Total & 477 \\
\hline
\end{tabular}

Table II Sera examined and with clinical diagnosis

\section{'COMMERCIAL' TESTS}

These were all carried out by one individual without knowledge of the clinical diagnosis, all tests being carried out as directed by the manufacturers. The sera were examined in batches, each batch consisting of a number of sera from each group. The individual tests on different batches were also carried out at intervals of time such that recall of the results in previous tests was extremely unlikely.

\section{ROSE-WAALER TEST}

The Rose-Waaler tests were performed by a second worker, again without knowledge of the clinical diagnosis. Sera to be tested were inactivated at $56^{\circ} \mathrm{C}$ for 30 minutes, and absorbed overnight at $4^{\circ} \mathrm{C}$ with an equal volume of washed unsensitized sheep red cells. The tests were performed using an $0.85 \%$ saline suspension of $1 \%$ sheep red cells optimally sensitized with rabbit antisheep red cell serum. Serial doubling dilutions of the sera were made in standard perspex agglutination trays. To $0.5 \mathrm{ml}$ of the serum dilutions was added $0.5 \mathrm{ml}$ of sensitized sheep red cells in one row and in a parallel row $0.5 \mathrm{ml}$ of unsensitized sheep red cells was added. After incubation for one hour at $37^{\circ} \mathrm{C}$ the trays were incubated overnight at $4^{\circ} \mathrm{C}$ and then read after leaving at room temperature for one hour. Agglutination of the sensitized cells at a serum dilution of $1 / 8$ or greater was regarded as positive.

\section{QUANTITATIVE STUDIES}

The sera selected for these studies were the first 200 giving a positive Rose-Waaler test. They were examined using the $\mathbf{R}_{\mathbf{3}}$ titration test (Warner) and the Bacto-rheumatoid titration test (Difco) which are marketed as quantitative tests for RF. Two of the screening reagents, namely, Rheumaton and Behringwerke-Latex RF reagents, were also used in these studies, these being chosen because they gave a good and poor concordance respectively with the Rose-Waaler results in the screening survey. The numbers of sera tested with each reagent (table V) were determined by the amounts of sera available.

\begin{tabular}{|c|c|c|c|c|c|c|c|c|}
\hline \multirow[t]{2}{*}{ Group } & \multirow[t]{2}{*}{ No. } & \multicolumn{7}{|c|}{ Concordance of Test Reagents with Rose-Waaler Result } \\
\hline & & Di $L$ & Di $S$ & $B e L$ & Hy L & $R_{\mathbf{a}} L$ & Rheum & We $L$ \\
\hline \multicolumn{9}{|c|}{ Rose-Waaler Positive } \\
\hline 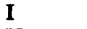 & 189 & 183 & 171 & 164 & 185 & 173 & 181 & 150 \\
\hline II & $3^{2}$ & 0 & 1 & 0 & 2 & 3 & 3 & 0 \\
\hline III & 37 & 23 & 13 & 13 & 29 & 11 & 24 & 11 \\
\hline IV & 29 & 22 & 15 & 15 & 23 & 19 & 22 & 13 \\
\hline Total & 258 & $228(88 \%)$ & $200(78 \%)$ & $192(74 \%)$ & $239(93 \%)$ & $206(80 \%)$ & $230(89 \%)$ & $174(67 \%)$ \\
\hline \multicolumn{9}{|c|}{ Rose-Waaler Negative } \\
\hline IIA & 51 & 39 & 46 & 49 & 40 & 48 & 47 & 48 \\
\hline B & 12 & 12 & 12 & 12 & 12 & 12 & 11 & 12 \\
\hline C & 11 & 11 & 11 & 11 & 11 & 11 & 10 & 11 \\
\hline D & 11 & 11 & 11 & 11 & 11 & 9 & 11 & 11 \\
\hline \multirow{3}{*}{ IV } & 63 & 57 & 63 & 63 & 38 & 62 & 60 & 63 \\
\hline & 71 & 66 & 71 & 70 & 64 & 68 & 69 & 70 \\
\hline & 219 & $196(89 \%)$ & $214(98 \%)$ & $216(99 \%)$ & $176(80 \%)$ & $210(96 \%)$ & $208(95 \%)$ & $215(98 \%$ \\
\hline \multicolumn{9}{|c|}{ Overall Concordance Results } \\
\hline
\end{tabular}

Table III Comparison of test reagents results with Rose-Waaler results

'Reiter's syndrome (1) and ankylosing spondylitis (2) 


\section{Results}

The results obtained with the various screening reagents are summarized in table III, being presented as the concordance between the Rose-Waaler results and the various reagents used. In the Rose-Waalerpositive series, HyL, Rheum, and DiL attained the best agreement, producing concordant results in 93, 89 , and $88 \%$ respectively. The remaining reagents gave $80 \%$ or less agreement. Examination of the discordant results is summarized in table IV in which the Rose-Waaler titres of the sera giving 'false-negative' results are shown. In the RoseWaaler-negative series only $\mathrm{HyL}$ and DiL fall below $90 \%$ agreement, at 80 and $89 \%$ respectively. The best agreement was attained by $\mathrm{BeL}, \mathrm{WeL}$, and $\mathrm{DiS}$, the three reagents, however, which gave the poorest concordance in the Rose-Waaler positive sera. The results of the quantitative survey are presented in table V. This shows that of the four reagents tested, the best correlation with the Rose-Waaler titre is obtained by $\mathbf{R}_{\mathbf{3}}$ and $\mathrm{Di}$ Tit, the two reagents which are marketed primarily for quantitation of RF. The Di Tit test is read before and after overnight incubation at $4^{\circ} \mathrm{C}$, and the prerefrigeration titre gives a slightly better correlation coefficient with the RoseWaaler titre.

\begin{tabular}{|c|c|c|}
\hline $\begin{array}{l}\text { Comparison } \\
\text { with Rose- } \\
\text { Waaler Test }\end{array}$ & No. Tested & Correlation Coefficient ${ }^{1}$ \\
\hline $\begin{array}{l}\text { Be L } \\
\mathbf{R}_{\mathbf{3}} \\
\text { Di Tit }\end{array}$ & $\begin{array}{l}199 \\
197 \\
171\end{array}$ & $\begin{array}{l}\gamma=0.4858 \\
\gamma=0.7496 \\
\text { Before refrigeration } \gamma=0.6783 \\
\text { After refrigeration } \gamma=0.6364\end{array}$ \\
\hline Rheum & 140 & $\gamma=0.5998$ \\
\hline
\end{tabular}

Table V Quantitation of rheumatoid factor

${ }^{1}$ Comparison of reciprocal of Rose-Waaler titre with reciprocal of titre in tests

\section{Discussion}

There is, as yet, no single test which combines the necessary specificity and sensitivity to make it in universally acceptable for RF screening. Hence the large number of currently available screening $\dot{\omega}$ reagents and the need to undertake this survey.

The Rose-Waaler test has been the test which has 0 been most used in examining sera for rheumatoid factor. It has to be recognized, however, that the $z$ test is not constant and variations in both methods and results are reported by different laboratories. $\vec{\varphi}$ Despite this it probably still remains the most widely used screening test in Great Britain, and in our own experience we have found the Rose-Waaler test to give a fairly good correlation with the clinical diagnosis. For these reasons we adopted it as the reference test with which to compare the various $\frac{Q}{\circ}$ commercial reagents. We are thus measuring con- $\stackrel{\circ}{\Rightarrow}$ cordance of the newer tests with the Rose-Waalerô을 test. Our findings give no indication of the relative diagnostic or prognostic merits of any of the tests.

The number of Rose-Waaler-positive sera in our group III is perhaps higher than expected. In this context, however, it is worth emphasizing that the group contained a large number of elderly osteo-3. arthritics, and in addition many of them had associated autoimmune diseases, Sjögren's disease in particular. In no instance, however, was there any을 clinical suspicion that these patients had or had had rheumatoid arthritis.

The results obtained in the Rose-Waaler-positive sera show that three of the reagents, HyL, Rheum, and DiL, are superior to the others, giving a low $N$ incidence of 'false-negative' results-7, 11, and N $12 \%$ respectively. This is further emphasized ono scrutiny of the results obtained in the Rose-Waaler negative sera, where it is seen that the remaining four reagents give the lowest incidence of 'false-positive? results. It would seem to us therefore that these four 0 reagents require more careful standardization.

It may be that the sensitivity of those reagents which have produced the poorest concordance have been deliberately set at such a level that 'falsepositive' reactions are minimized. However, the apparent need for more careful standardization is further substantiated when the 'false-negatives 
results are examined in comparison with the observed Rose-Waaler titre of these sera (table IV).

The HyL, which gave the best concordance with the Rose-Waaler-positive sera, attained only $80 \%$ concordance with the Rose-Waaler-negative sera. The reagents Rheum and DiL gave 95 and $89 \%$ concordance with seronegative sera. When this is taken in conjunction with their concordance of 89 and $88 \%$ respectively in the seropositive group, it would indicate that these two reagents show the most satisfactory overall agreement.

The final choice of the most satisfactory screening reagent must also take cognizance of the technical ease with which it can be used, and the relative marketing costs of the materials. The DiL has the disadvantage that the test sera have to be diluted 1 in 20 . In addition, we experienced some difficulty in reading the tests, some sera tending to produce some slight clumping when diluted in the recommended buffer. The Rheum reagent requires no serum dilution and is easy to read. We consider that it is probably the best of the currently available screening tests. The costs of the various reagents used are summarized in table $I$, these being presented as the estimated cost by the suppliers per 1000 sera. It is perhaps worth mentioning that it is possible for individual laboratories with a little trouble to make cheaply a latex reagent which can provide satisfactory screening results, for example, that described by Greenbury (1960).

The results obtained in the quantitation survey show that the $\mathbf{R}_{\mathbf{3}}$ and $\mathrm{Di}$ Tit were clearly superior to the Rheum and BeL. However, it has to be pointed out that the manufacturers do not in fact claim that Rheum can be used even as a semiquantitative test, and BeL gave poor concordance in the screening survey. The Di Tit is a tube titration method, which has the major disadvantage that it requires centrifugation before each reading, and in addition it is recommended that the tube be read both before and after overnight incubation at $4^{\circ} \mathrm{C}$. We experienced considerable difficulty in reading the endpoint of the test. The $\mathbf{R}_{3}$ test is also a tube titration one; it does not require any additional centrifugation, is extremely easy to read, and gave the best correlation with the Rose-Waaler titre.

\section{Reference}

Greenbury, C. 'L. (1960). A comparison of the Rose-Waaler, latex fixation, 'Ra-test' and Bentonite flocculation tests. J. clin. Path., 13, 325-330.

\section{Addendum}

Since these results were obtained the Rheum-Wellcotest has been recalibrated against the International Reference Standard and the manufacturers now claim improved sensitivity. 